\title{
MODELLING OF "GREEN" INVESTMENTS RISKS
}

\author{
V.G. Mokhov ${ }^{1}$, G.S. Chebotareva ${ }^{2}$, P.M. Khomenko ${ }^{2}$ \\ ${ }^{1}$ South Ural State University, Chelyabinsk, Russian Federation \\ ${ }^{2}$ Ural Federal University, Ekaterinburg, Russian Federation \\ E-mail: mokhov50@mail.ru, g.s.chebotareva@urfu.ru,pavelkhom@gmail.com
}

\begin{abstract}
The practical lack of methods for quantitative assessment of capital-intensive renewable energy projects taking into account the present uncertainty leads to an increase in the riskiness and reduce the amount of "green" investment in the economy. It resolves the urgency of the developing approaches to the renewable energy projects assessment. The article presents the diagnostics of specific risks and assessment of limiting the investor market share in the renewable energy projects with the optimal risk level. The proposed authors' approach to risks formalization of renewable energy deals is based on the introduction of dummy-variable, evaluation of coefficients' significance, tendency and strength of relation of risks indicators. This approach yields an indicative assessment of the deals' riskiness taking into account sectoral specifics. The developed method to limiting the investor market share is based on the principles of the economic capital theory. It allows for consolidating the current states of investor, project and economy. Research veracity is confirmed by the practical implementation. The results of the study can be used by the management of energy companies, investors and analysts in making financial decisions.
\end{abstract}

Keywords: renewable energy; "green" investment; modeling; indicator; risks' formalization; limiting investor market share; risk-capital.

\section{Introduction}

The share of conventional hydrocarbon energy in Russia is about $65 \%$. The structure of this fuel and energy balance in the Russian power sector will not change significantly till 2020. The concept of sustainable development aimed at the rational use of natural resources without compromising the current and future generations, raises the problem of the transition to renewable energy (RE) in priority. Phased transition to new energy generation technologies, accelerated development of renewable energy, development of systems Smart Grid, tightening climate conditions require the increasing amount of "green" investment [1].

At the present time the "green" energy projects are characterized as highly risky. In this regard, the problem of modelling and reducing the level of specific risks' in the renewable energy projects is highly actual and practically significant [2-4]. The decision of the problem involves two main stages.

\section{Formalization of RE Investment Risks}

In the framework of this stage the logit-model (1) as the most popular one for default probability forecasting is used:

$$
P D=\frac{1}{1+e^{-z}},
$$

where $\mathrm{PD}$ is probability of RE project default; parameter

$$
z=\left(b_{0}+b_{1} \cdot X_{i 1}+b_{2} \cdot X_{i 2}+\ldots+b_{n} \cdot X_{i n}\right),
$$


$X_{i j}$ is value of $j$-th financial indicator for $i$-th project; $b_{j}$ is evaluation value of $j$-th coefficient' significance.

The assessment of parameters' significance for model " $b_{j}$ " is based on Student's test (3) for hypothesis $b_{j}=0[5]$ :

$$
t_{b j}=b_{j} \cdot \sqrt{\frac{\sum_{j=1}^{n}\left(X_{i j}-\overline{X_{i j}}\right)}{S}},
$$

where $\overline{X_{i j}}$ is the average value of $j$-th financial indicator for $i$-th project; $\mathrm{S}$ is sampling residual standard deviation.

The empiric base of study for logit-model assessment was formed by experts' opinion. It includes eight specific risks indicators for RE project. Financial stability of RE project is evaluated by: Debt Service Coverage Ratio $X_{i 1}$; Working Capital to Current Assets $X_{i 2}$; Internal Rate of Return $X_{i 3}$; Discounted Payback Period $X_{i 4}$; Level of Financial Stress $X_{i 5}$. Institutional assessment of RE project is based on introduction of the following dummyvariable: Indicator of project type $X_{i 6}$ is changed by three parameters: new construction Inst 1 , overhaul Inst 2 or modernization Inst 3 and obey (4); Level of market risk $X_{i 7}$ is changed from low Inst 4 to high Inst 6 and obey (5); Level of goodwill $X_{i 8}$ characterizes the field experience of RE project: from lack of skill Inst 9 to more than three projects Inst7 (conditions 6):

$$
\begin{gathered}
\text { Newconstruction }=\left\{\begin{array}{l}
\text { Inst } 1=1, \\
\text { Inst } 2=0, \\
\text { Inst } 3=0,
\end{array}\right. \\
\text { Overhaul }=\left\{\begin{array}{l}
\text { Inst } 1=0, \\
\text { Inst } 2=1, \\
\text { Inst } 3=0,
\end{array}\right. \\
\text { Modernization }=\left\{\begin{array}{l}
\text { Inst } 1=0, \\
\text { Inst } 2=0, \\
\text { Inst } 3=1,
\end{array}\right.
\end{gathered}
$$

$$
\begin{gathered}
\text { Lowrisks }=\left\{\begin{array}{l}
\text { Inst } 4=1, \\
\text { Inst } 5=0, \\
\text { Inst } 6=0,
\end{array}\right. \\
\text { Averagerisk }=\left\{\begin{array}{l}
\text { Inst } 4=0, \\
\text { Inst } 5=1, \\
\text { Inst } 6=0,
\end{array}\right. \\
\text { Highrisk }=\left\{\begin{array}{l}
\text { Inst } 4=0, \\
\text { Inst } 5=0, \\
\text { Inst } 6=1,
\end{array}\right.
\end{gathered}
$$




$$
\begin{gathered}
\text { Highgoodwill }=\left\{\begin{array}{l}
\text { Inst } 7=1, \\
\text { Inst } 8=0, \\
\text { Inst } 9=0,
\end{array}\right. \\
\text { Averagelevelof goodwill }=\left\{\begin{array}{l}
\text { Inst } 7=0, \\
\text { Inst } 8=1, \\
\text { Inst } 9=0,
\end{array}\right.
\end{gathered}
$$

As a result the adjusted parameter " $z$ " for formula (1) takes the following form for the RE project:

$$
\begin{gathered}
z=0,5578-1,785 \cdot X_{i 1}-0,237 \cdot X_{i 2}-0,008 \cdot X_{i 3}+0,018 \cdot X_{i 4}-1,284 \cdot X_{i 5}+ \\
+0,459 \cdot X_{i 6}+0,167 \cdot X_{i 7}+0,091 \cdot X_{i 8}
\end{gathered}
$$

The results of coefficient interpretations as well as its tendency and strength of relation are presented in Table 1. The analisis shows Debt Service Coverage Ratio $X_{i 1}$ and Level of Financial Stress $X_{i 5}$ exert the greatest influence on RE project results. Consequently, the corresponding risks are deemed to be most dangerous for the RE project.

Table 1

Results of risks' indicators formalization

\begin{tabular}{|l|l|l||l|l|l|}
\hline Indicator & $\begin{array}{l}\text { Tendency and } \\
\text { strength } \\
\text { relation }\end{array}$ & Coefficient & Indicator & $\begin{array}{l}\text { Tendency and } \\
\text { strength } \\
\text { relation }\end{array}$ & Coefficient \\
\hline$X_{i 1}$ & +++ & $-1,785$ & $X_{i 5}$ & +++ & $-1,284$ \\
\hline$X_{i 2}$ & ++ & $-0,237$ & $X_{i 6}$ & -- & 0,459 \\
\hline$X_{i 3}$ & + & $-0,008$ & $X_{i 7}$ & - & 0,167 \\
\hline$X_{i 4}$ & - & 0,018 & $X_{i 8}$ & - & 0,091 \\
\hline
\end{tabular}

\section{Limiting the Investor Market Share in Financing Renewable Energy}

To ensure sustainability the investor determines the acceptable risk level based on the maximum losses that reduce the operation disturbance and temporary insolvency. It is the first absolute limitation the investor shares in the RE project (formula 8):

$$
N C A P=C C A P-T C A P,
$$

where NCAP is the investor' capital the loss of which would not lead to insolvency; $C C A P$ is the current capital of the investor; $T C A P$ is the target capital to cover overall risk of the investor (in the case of project default). The volume of $T C A P$ is calculated using the credit rating and counterpart of confidence probability by formula (9) and Table 2:

$$
T C A P=P_{S \& P} \cdot C C A P,
$$

where $P_{S \& P}$ is confidence probability value by project duration and rating. 
Table 2

Confidence probability value \% (Standard \& Poor Global Ratings)

\begin{tabular}{|l|l|l|l||l|l|l|l|}
\hline Rating & 1-Y PD & $3-\mathrm{Y}$ PD & 5 -Y PD & Rating & 1-Y PD & 3-Y PD & 5-Y PD \\
\hline AAA & 0,008 & 0,03 & 0,1 & BB & 1,15 & 8,6 & 15 \\
\hline AA & 0,04 & 0,16 & 0,28 & B & 5,8 & 15,4 & 32,6 \\
\hline A & 0,16 & 0,4 & 0,58 & $\begin{array}{l}\text { CCC or } \\
\text { lower }\end{array}$ & 26,57 & 45,5 & 60 \\
\hline BBB & 0,3 & 1,4 & 3 & X & X & X & X \\
\hline
\end{tabular}

The second absolute limitation is the exposure at default value $E A D[2]$ - the potential volume of project obligations at the time of default:

$$
E C A P=E A D \cdot L G D \cdot\left(N\left(\frac{N^{-1}(P D)+N^{-1}(\alpha) \cdot \sqrt{r}}{\sqrt{1-r}}\right)-P D\right),
$$

where $L G D$ is loss given default; $\mathrm{N}()$ is standard normal distribution; $N^{-1}()$ is inverse standard normal distribution; is reliability level; $r$ is correlation coefficient between the states of the project and the region economy; $E C A P$ is overall value of the project economic capital. Parameter $E C A P$ is also calculated for every separated risk in accordance with condition (11). It is an example of three most dangerous existing risks below:

$$
E C A P=\sqrt{E C A P_{1}^{2}+E C A P_{2}^{2}+E C A P_{3}^{2}+A+B+C},
$$

where $A=2 \cdot E C A P_{1} \cdot E C A P_{2} \cdot \rho_{12}, B=2 \cdot E C A P_{1} \cdot E C A P_{3} \cdot \rho_{13}, C=2 \cdot E C A P_{2} \cdot E C A P_{3} \cdot \rho_{23}$. $E C A P_{1}, E C A P_{2}, E C A P_{3}$ are the capital values for the first, second and third risks; $\rho_{12}$, $\rho_{23}, \rho_{13}$ are correlation coefficients between two risks' components. Subject to conditions (8) - (11) the absolute maximum limiting amount of investments in RE project is calculated by (12):

$$
L F=\min (N C A P ; E A D),
$$

where LF is the limiting volume of investments. The limiting share can be corrected additionally by parameter " $K$ " for the RE projects with high riskiness. It depends on the risks level: PD and LGD. For the purposes of further indication, these indicators were put together in (13):

$$
E L=P D \cdot L G D
$$

where EL is the level of expected RE project losses. Experts' assessment of dependence between EL and $\mathrm{K}$ is presented in Table 3.

Table 3

Correspondence between the K-factor and EL-level

\begin{tabular}{|c|c|c|c|c|c|c|c|c|}
\hline EL & $0-0,05$ & $0,06-0,1$ & $0,11-0,15$ & $0,16-0,3$ & $0,31-0,7$ & $0,71-1,2$ & $1,21-2$ & $2,1-3,5$ \\
\hline K & 1 & 0,99 & 0,97 & 0,95 & 0,93 & 0,9 & 0,85 & 0,8 \\
\hline EL & $3,51-5$ & $5,01-8$ & $8,01-10$ & $10,01-25$ & $25,01-32$ & $32-45$ & $45-75$ & $75-100$ \\
\hline K & 0,75 & 0,65 & 0,5 & 0,35 & 0,1 & 0,005 & 0,0001 & 0 \\
\hline
\end{tabular}


The relative value of investor market share is calculated based on (12) and supplemented with total RE project budget amount and parameter " $K$ ":

$$
L F=\frac{\min (N C A P ; K \cdot E A D)}{B D G},
$$

where $B D G$ is the total budget of renewable energy project.

\section{Conclusions}

1. A topical problem of qualitative assessment of "green" projects is solved.

2. The results are recommended for the use in the development of risk-management programme in energy companies and for private investors.

3. The developed approaches of risks' formalization and limiting the investor market share for renewable energy projects allow improve their attractiveness.

Acknowledgements. The work was supported with a grant of the Russian Science Foundation (project No. 17-78-10039) (chapter 1 and 2) and by Act 211 Government of the Russian Federation, contract No. 02.A03.21.0011 (chapter 2).

\section{References}

1. Porfir'ev B.N. Green Trends in the Global Financial System. World Economy and International Relationships, 2016, vol. 60, no. 9, pp. 5-16. DOI: 10.20542/0131-2227-201660-9-5-16

2. Cleijne H., Ruijgrok W. Modelling Risks of Renewable Energy Investments: Green-X Project. Within the 5th Framework Programme of the European Commission Supported by DG Research, KEMA (The Netherlands), July, 2004, 2004, 74 p., available at: http://www.greenx.at/downloads/WP2 - Modelling risks of renewable energy investments (Green-X).pdf

3. Ross B., Lopez-Alcala M., Small A. Modeling the Private Financial Returns from Green Building Investments. Journal of Green Building, 2007, no. 2 (1), pp. 97-105.

4. Mokhov V.G., Chebotareva G.S., Demyanenko T.S. Complex Approach to Assessment of Investment Attractiveness of Power Generating Company. Bulletin of the South Ural State University. Series: Mathematical Modelling, Programming and Computer Software, 2017, vol. 10 , no. 2, pp. 150-154. DOI: $10.14529 / \mathrm{mmp} 170213$

5. Simchera V.M. Metody mnogomernogo analiza statisticheskih dannyh [Methods of Multivariate Analysis of Statistical Data]. Moscow, Finansy i statistika, 2008. 400 p. (in Russain)

Received March 14, 2018

УДК 330.322.013+001.895

DOI: $10.14529 / \mathrm{mmp} 180213$

\section{МОДЕЛИРОВАНИЕ РИСКОВ «ЗЕЛЕНЫХ ИНВЕСТИЦИЙ}

\section{В.Г. Мохов ${ }^{1}$, Г.С. Чеботарева ${ }^{2}$, П.М. Хоменко}

${ }^{1}$ Южно-Уральский государственный университет, г. Челябинск,

Российская Федерация

${ }^{2}$ Уральский федеральный университет, г. Екатеринбург, Российская Федерация

Практическое отсутствие методов количественной оценки капиталоемких проектов в сфере возобновляемой энергетики с учетом существующей неопределенности 
ведет к повышению рискованности сделок в данной сфере и способствует снижению объема «зеленых» инвестиций в экономике. Это предопределило актуальность разработки подходов к оценке проектов по возобновляемой энергетике при их реализации. Статья посвящена диагностике состояния специфических рисков и оценке предельной доли участия инвесторов в проектах возобновляемой энергетики, с учетом обеспечения оптимального уровня риска. Предложен авторский поход к формализации рисков финансирования возобновляемой энергетики на основе введения dummyпеременных, оценки значимости коэффициентов, а также направления и силы связи риск-индикаторов. Он позволяет получить индикативную оценку степени рискованности сделки с учетом отраслевых особенностей. Разработанный метод ограничения доли участия инвестора в проекте, основанный на базовых принципах теории экономического капитала, позволяет консолидировано учитывать текущее состояние инвестора, проекта и экономики. Достоверность результатов исследования подтверждена практической реализацией. Результаты исследования рекомендуется использовать менеджментом энергокомпаний, инвесторам и аналитикам в процессе принятия финансовых решений.

Ключевые слова: возобновляемая энергетика; «зеленые» инвестиции; моделирование; индикатор; формализация рисков; ограничение доли инвестора; риск-капитал.

\section{Литература}

1. Порфирьев, Б. «Зеленые» тенденции в мировой финансовой системе / Б. Порфирьев // Мировая экономика и международные отношения. - 2016. - Т. 60, № 9. - С. 5-16.

2. Cleijne, H. Modelling Risks of Renewable Energy Investments: Green-X Project / H. Cleijne, W. Ruijgrok // Within the 5th Framework Programme of the European Commission Supported by DG Research, KEMA (The Netherlands), July, 2004 [Электронный ресурс]. 2004. - 74 p. - URL: http://www.green-x.at/downloads/WP2 - Modelling risks of renewable energy investments (Green-X).pdf

3. Ross, B. Modeling the Private Financial Returns from Green Building Investments / B. Ross, M. Lopez-Alcala, A. Small // Journal of Green Building. - 2007. - № 2 (1). - P. 97-105.

4. Mokhov, V.G. Complex Approach to Assessment of Investment Attractiveness of Power Generating Company / V.G. Mokhov, G.S. Chebotareva, T.S. Demyanenko // Вестник ЮУрГУ. Серия: Математическое моделирование и программирование. - 2017. - Т. 10, № 2. - С. 150-154.

5. Симчера, В.М. Методы многомерного анализа статистических данных / В.М. Симчера. М.: Финансы и статистика, 2008. - 400 с.

Вениамин Геннадьевич Мохов, доктор экономических наук, профессор, кафедра «Математическое и компьютерное моделирование», Южно-Уральский государственный университет (г. Челябинск, Российская Федерация), mokhov50@mail.ru.

Галина Сергеевна Чеботарева, кандидат экономических наук, доцент, старший научный сотрудник, кафедра «Системы управления энергетикой и промышленными предприятиями», Уральский федеральный университет (г. Екатеринбург, Российская Федерация), g.s.chebotareva@urfu.ru.

Павел Михайлович Хоменко, старший преподаватель, кафедра «Банковский и инвестиционный менеджмент», Уральский федеральный университет (г. Екатеринбург, Российская Федерация), pavelkhom@gmail.com.

\section{Поступила в редакиию 14 марта 2018 г.}

